\title{
DELAY IN INTRODUCING ANTIRETROVIRAL THERAPY IN PATIENTS INFECTED BY HIV IN BRAZIL, 2003-2006
}

\author{
Paulo Roberto Borges Souza-Jr'1 ${ }^{1}$, Celia Landmann Szwarcwald ${ }^{1}$, Euclides Ayres \\ Castilho $^{2}$
}

Souza-Jr, PRB, Szwarcwald CL, Castilho EA. Delay in introducing antiretroviral therapy in patients infected by HIV in Brazil, 2003-2006. Clinics. 2007; 62(5):579-84.

PURPOSE: To characterize the population of HIV+ Brazilian patients with late introduction of antiretroviral therapy (ARVT), using information from the Laboratory Exam Control System.

METHODS: The study analyzed 84,694 patients, representing all individuals in Brazil age 15 or over with an initial CD4+ $\mathrm{T}$ lymphocyte count requested between 2003 and 2006, and whose ARVT start date was later than their initial CD4+ T cell count. These patients were considered antiretroviral treatment naive. The initial CD4 ${ }^{+} \mathrm{T}$ cell distribution was analyzed according to sex, age, region and year.

RESULTS: Most of the patients were between 15 and 49 years of age (91\%); 56\% were males; 76\% were asymptomatic; 50\% lived in the Southeastern region of the country, with an additional $20 \%$ in the South. Initial CD $4^{+}$counts for one-third of the patients were less than 200 cells $/ \mathrm{mm}^{3}$. When combined with the number of symptomatic individuals, $41 \%$ of the total group was in need of immediate ARVT. This group included $47 \%$ of the men and $53 \%$ of the patients aged 50 years and over.

CONCLUSIONS: Despite universal access to ARVT in Brazil, results show that a high proportion of patients initiate ARVT at an advanced stage of disease, indicating the need to develop strategies to promote early diagnosis of HIV infection nationwide.

KEY-WORDS: CD4+ T lymphocytes. HIV. AIDS. Antiretroviral therapy. Brazil.

\section{INTRODUCTION}

The quality of life of people living with HIV/AIDS has improved drastically with the introduction of highly active antiretroviral therapy (HAART), resulting in a significant reduction of viral load and an increase of the $\mathrm{CD} 4^{+} \mathrm{T}$ lymphocyte count among treatment-naive patients ${ }^{1}$.

However, access to HAART is uneven, and varies depending on public policies and treatment costs in each country. In Latin America, according to information from national AIDS programs, ARVT coverage varies from $15 \%$

${ }^{1}$ Oswaldo Cruz Foundation - Department of Information in Health

${ }^{2}$ São Paulo University Medical School - Department of Preventive Medicine

Email: pborges@cict.fiocruz.br

Received for publication on April 27, 2007

Accepted for publication on July 02, 2007 in Peru to $100 \%$ in Argentina, Brazil and other countries ${ }^{2}$.

In Brazil, the Ministry of Health began distributing drugs for prophylaxis and treatment of opportunistic infections in the mid-1980s. AZT (zidovudine) was the first drug available in Brazil, beginning in 1991. The combined effort of patients, civil society groups, and government agencies resulted in the passage of a federal law in 1996 guaranteeing the right of all individuals with HIV/AIDS to receive the drugs necessary for their treatment free of charge ${ }^{3}$.

The high cost of antiretroviral therapies and the growing number of patients in need of them have been a continuing challenge for the Ministry of Health. Brazil has adopted several strategies to reduce the cost of ARVT, including local production of drugs and negotiations with international pharmaceutical companies to provide drugs at lower cost. As a result, the government has been able to 
maintain its commitment despite the increased number of patients under treatment and the increased proportion of them who require more expensive and complex treatment schemes. ${ }^{4}$ Universal distribution of ARV drugs has resulted in an improved quality of life for patients, as well as increased survival and a significant reduction in hospitalizations. ${ }^{5,6,7}$

The public health system provides all necessary laboratory tests for HIV diagnosis and patient follow-up. ${ }^{8}$ In recent years, public health policies have been implemented to encourage periodic HIV testing amongst the general population. For example, HIV testing has become a routine part of prenatal care.

However, data from the 2004 Brazilian Knowledge, Attitudes and Practices Survey show that only $28 \%$ of individuals have been tested even once for HIV. ${ }^{9}$ Thus, despite the undisputed impact of universal ARVT, many individuals potentially in need of ARVT delay the initiation of treatment or have inadequate follow-up and adherence.

The Laboratory Exam Control System (SISCEL) was created in Brazil with the aim of monitoring laboratory procedures associated with CD4+/CD8+ T lymphocyte counts and viral load quantification. These exams are performed to determine the need for treatment and to monitor the disease evolution of patients receiving ARVT. This article is based on SISCEL data, and addresses the problem of late initiation of therapy in Brazil.

\section{MATERIALS AND METHODS}

SISCEL is made up of three sub-systems, one of which includes patient information, while the other two include information on laboratory test results for viral load and the $\mathrm{CD}^{+} \mathrm{T}$ lymphocyte count. The sub-systems are linked by a patient identification code, and are fed by two public health laboratory networks implemented in 1997 (one for $\mathrm{CD}^{+} / \mathrm{CD}^{+}{ }^{+} \mathrm{T}$ cell count exams and the other for viral load exams). Currently, these networks include 88 laboratories for $\mathrm{T}$ cell counts and 72 for viral load quantification, located in every state in the nation.

For the present study, SISCEL data from 2003-2006 was requested by the National STD/AIDS Program (PN-DST/ AIDS). Occasionally, duplicates occur in the register, in which the same patient appears in the system with different codes. The National Program uses a method to detect these duplicates so that each patient is counted only once. This method involves establishing a "key field" and using the Reclink application to search for phonetic key patterns. The "key-field" is composed of the concatenation of the first and last names, birth date, sex and the code of the state of residence. This paper analyzed the SISCEL database without duplicates and without patient identity, so patient consent was not required.

The following SISCEL variables were analyzed: initial $\mathrm{CD}^{+} \mathrm{T}$ lymphocyte counts, age, sex, infection status (symptomatic, asymptomatic), reason for the exam (evaluation of treatment indication, ARVT monitoring, therapeutic scheme change), date of exam request and date of ARVT initiation.

The study sought to assess the patients' immunologic status at the date of the first $\mathrm{CD} 4^{+} \mathrm{T}$ lymphocyte count. All individuals aged 15 years and over with an initial $\mathrm{CD} 4^{+} \mathrm{T}$ lymphocyte count between 2003 and 2006, and for whom the initial therapy start date was later than the $\mathrm{CD}^{+} \mathrm{T}$ cell exam request were included in the analysis. These patients were considered ARVT naïve, and the date of the exam request was considered the first evaluation for initiating therapy. Among ARVT naïve patients, the distribution of initial $\mathrm{CD} 4^{+} \mathrm{T}$ lymphocyte counts was analyzed.

In order to obtain the proportion of patients with delayed initiation of ARVT, $\mathrm{CD} 4^{+} \mathrm{T}$ lymphocyte counts were classified into three categories: in need of therapy $(<200$ $\mathrm{CD}^{+} \mathrm{T}$ cells/ $\left.\mathrm{mm}^{3}\right)$; under observation $\left(200-349 \mathrm{CD}^{+} \mathrm{T}\right.$ cells $\left./ \mathrm{mm}^{3}\right)$; and no indication for therapy $\left(\geq 350 \mathrm{CD}^{+} \mathrm{T}\right.$ cells $/ \mathrm{mm}^{3}$ ), according to the Ministry of Health's “Anti Retroviral Therapy Recommendations for Adults and Adolescents Infected by HIV"11.

Patients included in the study were characterized by sex; age (15-49 years of age and 50 years and over); presence or absence of symptoms; and macro-region of residence (North, Northeast, Southeast, South, or Central-West).

Finally, the proportion of treatment-naive patients that fit the criteria for immediate initiation of treatment was established by adding the number of patients with $\mathrm{CD} 4^{+} \mathrm{T}$ lymphocyte counts $<200 \mathrm{cell} / \mathrm{mm}^{3}$ to the number of symptomatic patients with $\mathrm{CD} 4^{+} \mathrm{T}$ counts $\geq 200 \mathrm{cell} / \mathrm{mm}^{3}$.

\section{RESULTS}

Between 2003 and 2006, 84,694 patients had their first $\mathrm{CD}^{+} \mathrm{T}$ lymphocyte count for evaluation of ARVT indication. Of these, 16,659 had their first exam in 2003; 20,285 in 2004; 24,249 in 2005 and 23,501 in 2006. Most of the patients were between 15 and 49 years old (91\%), and 56\% were males. Seventy-six percent were asymptomatic. Fifty percent lived in the Southeast, $20 \%$ in the South, $18 \%$ in the Northeast, $7 \%$ in the Central-West region and 5\% in the North (Table 1).

The median initial $\mathrm{CD}^{+} \mathrm{T}$ lymphocyte count was 326 cells $/ \mathrm{mm}^{3}$ (290 cells $/ \mathrm{mm}^{3}$ for men vs. 368 cells $/ \mathrm{mm}^{3}$ for women), that is, more than $50 \%$ of the patients were in a disease stage in which ARVT initiation would be recom- 
Table 1 - Distribution of treatment-naïve patients by sex, age, presence of symptoms, region of residence and year of exam request. Brazil, 2003-2006.

\begin{tabular}{lcc}
\hline Characteristics & $\mathrm{N}$ & $\%$ \\
\hline Sex & & \\
$\quad$ Female & 37541 & 44.4 \\
$\quad$ Male & 47059 & 55.6 \\
Age group (in years) & & \\
$\quad$ 15-49 & 76940 & 90.8 \\
$\quad$ 50 and over & 7756 & 9.2 \\
Presence of symptoms & & \\
$\quad$ Asymptomatic & 62143 & 76.1 \\
$\quad$ Symptomatic & 19559 & 23.9 \\
Region & & \\
$\quad$ North & 4360 & 5.4 \\
$\quad$ Northeast & 14309 & 17.9 \\
$\quad$ Southeast & 39792 & 49.7 \\
$\quad$ South & 16034 & 20.0 \\
$\quad$ Central-West & 5644 & 7.0 \\
\hline
\end{tabular}

mended depending on viral load and the presence of symptoms.

Table 2 shows the proportion of patients that had $\mathrm{CD} 4^{+}$ counts less than 200 cells $/ \mathrm{mm}^{3}$ by sex, age, region of residence, year and presence of symptoms. This proportion is greater among men $(38 \%)$ than among women $(27 \%)$. Patients over 50 years old presented the most critical situation $(44 \%)$ when compared to the younger individuals $(32 \%)$. There was significant regional variation as well. The

Table 2 - Distribution (\%) of CD4+ $4^{+}$lymphocyte counts among treatment-naïve patients by sex, age group, presence of symptoms, region of residence and year of exam request. Brazil, 2003-2006.

\begin{tabular}{llll}
\hline Patient characteristics & \multicolumn{3}{c}{ CD4 $4^{+}$T lymphocyte count $\left(\mathrm{cell} / \mathrm{mm}^{3}\right)$} \\
& $<200$ & Between 200 and 350 & $>350$ \\
\hline Sex & & & \\
$\quad$ Female & 26.6 & 20.8 & 52.6 \\
$\quad$ Male & 37.8 & 20.4 & 41.9 \\
Age group (in years) & & & \\
$\quad$ 15-49 & 31.7 & 20.4 & 47.9 \\
$\quad$ 50 and over & 43.7 & 21.7 & 34.6 \\
Presence of symptoms & & & \\
$\quad$ Asymptomatic & 22.7 & 22.2 & 55.1 \\
$\quad$ Symptomatic & 65.1 & 15.2 & 19.6 \\
Region & & & \\
$\quad$ North & 40.5 & 22.3 & 37.2 \\
$\quad$ Northeast & 36.5 & 20.0 & 43.5 \\
$\quad$ Southeast & 31.5 & 20.1 & 48.4 \\
$\quad$ South & 28.0 & 22.3 & 49.7 \\
$\quad$ Central-West & 38.0 & 19.7 & 42.3 \\
Year of exam request & & & \\
2003 & 32.9 & 21.5 & 45.6 \\
$\quad$ 2004 & 31.8 & 20.7 & 47.5 \\
$\quad$ 2005 & 32.1 & 20.4 & 47.5 \\
2006 & 34.3 & 19.9 & 45.8 \\
\hline Total & 32.8 & 20.5 & 46.7 \\
\hline
\end{tabular}

North, although with fewer patients, possessed the greatest proportion of late initiators $(40 \%)$. The Central-West region (38\%) and the Northeast (36\%) also presented values higher than the national average (33\%). There was little variation (32\%-34\%) from year to year. As for opportunistic infections among symptomatic patients, only $20 \%$ had $\mathrm{CD} 4^{+}$counts greater than 350 cells $/ \mathrm{mm}^{3}$. As expected, more of the asymptomatic patients had higher $\mathrm{T}$ cell counts $(55 \%)$.

Table 3 shows the estimated proportion of patients with an indication for immediate treatment $\left(\mathrm{CD} 4^{+}\right.$count less than 200 cells $/ \mathrm{mm}^{3}$ or symptomatic). This group comprised $41 \%$ of all patients, $47 \%$ of the men and $53 \%$ of those over 50 years of age. By geographic region, the lowest value was $35 \%$ in the South, reaching as high as $50 \%$ in the North.

Table 3 - Proportion of ARVT naive patients that fit the criteria for immediate initiation of ARVT $\left(<200 \mathrm{CD}^{+} \mathrm{T}\right.$ cells $/ \mathrm{mm}^{3}$ or symptomatic) according to sex, age group, region of residence and year of exam request. Brazil, 20032006.

\begin{tabular}{lcc}
\hline Patient characteristics & $\begin{array}{c}\text { Recommendation for ARVT initiation }(\%) \\
\text { YES }\end{array}$ & NO \\
\hline Sex & 33.4 & 66.6 \\
$\quad$ Female & 46.8 & 53.2 \\
$\quad$ Male & & \\
Age Group & 39.6 & 60.4 \\
$\quad$ 15-49 years & 52.9 & 47.1 \\
$\quad$ 250 years & & \\
Region & 50.0 & 50.0 \\
$\quad$ North & 46.5 & 53.5 \\
$\quad$ Northeast & 39.1 & 60.9 \\
$\quad$ Southeast & 34.9 & 65.1 \\
$\quad$ South & 45.0 & 55.0 \\
$\quad$ Central-West & & \\
Year of exam request & 41.2 & 58.8 \\
$\quad$ 2003 & 39.8 & 60.2 \\
2004 & 39.9 & 60.1 \\
2005 & 42.4 & 57.6 \\
$\quad 2006$ & 40.8 & 59.2 \\
\hline Total & & \\
\hline
\end{tabular}

\section{DISCUSSION}

Without treatment, HIV-infected patients take an average of 8 years to reach an advanced stage of disease, when $\mathrm{CD}^{+}$counts fall to values less than 200 cells $/ \mathrm{mm}^{3}$ and opportunistic diseases begin to develop. ${ }^{1}$ It is during this symptomatic phase that individuals who do not know their serological status typically seek medical assistance.

Unknown serostatus is the principal factor associated with the late arrival of HIV-infected individuals to the health system. This not only favors the spread of the vi- 
rus, but also makes these patients more difficult to treat, since patients that begin treatment with low $\mathrm{CD}^{+} \mathrm{T}$ cell counts (especially below 50 cells $/ \mathrm{mm}^{3}$ ) typically have a poorer response to antiretroviral therapy. ${ }^{12,13,14}$

Several studies have addressed the problems associated to ${ }^{15}$ and the need for an early diagnosis of HIV infection. The proportion of patients with delayed initiation of ARVT varies widely according to region, but is generally significant ${ }^{16}$. In the United States, Klein et al. (1998) analyzed data regarding HIV-infected patients from an integrated health care system. Among them, $62 \%$ presented $\mathrm{CD} 4^{+} \mathrm{T}$ counts lower than 350 cells $/ \mathrm{mm},{ }^{3}$ and $43 \%$ were less than 200 cells $/ \mathrm{mm}^{3}$. Another survey carried out in South Carolina (USA) between 2000 and 2003 showed that $50 \%$ of treatment-naive patients presented $\mathrm{CD} 4{ }^{+} \mathrm{T}$ cell counts lower than 200 cells $/ \mathrm{mm}^{3}{ }^{18}$ Studies in Italy ${ }^{19}$ and in French Guiana ${ }^{20}$ presented values greater than $30 \%$.

In the case of Brazil, information on initial $\mathrm{CD} 4^{+} \mathrm{T}$ cell counts is available at the national level through SISCEL, forming the basis of the present analysis. The system is representative of the exams conducted by the public health system in the five regions because the $\mathrm{CD} 4^{+} \mathrm{T}$ cell count is considered a high complexity exam which must be registered in order for the laboratory to be reimbursed by the Brazilian health system. Although the system is limited to the network of public laboratories, it is believed to cover most HIV-infected patients, since only approximately $24 \%$ of the Brazilian population is estimated to have a private health plan, ${ }^{21}$ and several health plans do not cover this type of exam.

One limitation of our study is that we assumed the $\mathrm{CD} 4^{+}$ $\mathrm{T}$ cell count request date to be the first evaluation for the indication of therapy initiation, but in a few cases, the first exam could have been performed by a private lab or a lab outside of the public network.

Of all the patients analyzed in this study, the National STD/AIDS Program found that about $2 \%$ of cases were duplicates. These are patients that were tested in different laboratories and received different identification codes. The previously described method of screening for duplicates was proposed by the National Program and has been routinely adopted for all databases of the program ${ }^{22}$. Had these duplicates not been screened out, this would represent a potential bias, since a number of second exams would have been counted as first ones.

The SISCEL data analyzed for the period between 2003 and 2006 showed that around one-third of the HIV-infected individuals had a $\mathrm{CD}^{+} \mathrm{T}$ lymphocyte count of less than 200 cells $/ \mathrm{mm}^{3}$ at initial presentation. When combined with symptomatic individuals, these findings indicate that $41 \%$ were in need of immediate treatment at presentation. These results were unexpected, because Brazil is a country where HIV testing, $\mathrm{CD}^{+}$monitoring, and antiretroviral treatment are offered to the population free of charge.

Another possible analysis based on the SISCEL data is to consider the time between the first $\mathrm{CD}^{+} \mathrm{T}$ lymphocyte count and the initiation of therapy. This paper considered the analysis of patients' immunologic status at the date of the first $\mathrm{CD} 4^{+} \mathrm{T}$ lymphocyte count because the main cause of delayed ARVT initiation is the late diagnosis, rather than access to therapy.

Like Brazil, England has a surveillance system of $\mathrm{CD} 4^{+}$ T lymphocyte count exams. According to Gupta et al. ${ }^{23}$, the system covers $88 \%$ of all exams performed in England and Wales. The authors analyzed patients that had their first $\mathrm{CD}^{+} \mathrm{T}$ lymphocyte count within a period of 6 months after initial HIV diagnosis (considered treatment naïve), and found that about $37 \%$ of the patients had $\mathrm{CD}^{+} \mathrm{T}$ counts lower than 200 cells $/ \mathrm{mm}^{3}$ between 1990 and 1998. In 2003, differences were found by analyzing the same information system by risk category: among men that have sex with other men, the proportion was much lower $(21 \%)$ than among heterosexuals $(40 \%){ }^{24}$

For countries that do not have registries of initial CD4 ${ }^{+}$ $\mathrm{T}$ lymphocyte counts, other criteria have been adopted to estimate the delay in initiating therapy, such as the time between HIV notification and AIDS diagnosis. A short span, in general less than two months, would indicate a late detection of HIV infection. In Spanish studies of AIDS cases diagnosed between 1994 and 2000, 28\% of patients discovered that they were seropositive within 2 months of AIDS diagnosis. ${ }^{25}$

Literature on the topic emphasizes several factors that may be associated with delay in initiating therapy, among them, risk category (especially heterosexuals), age (especially older adults), sex (males, since women are often tested during pregnancy), as well as other cultural, political, and economic factors. ${ }^{17,19,26}$

In Brazil, women of reproductive age are routinely screened for HIV during pregnancy, as recommended by the Ministry of Health. Detection of HIV infection during prenatal care also promotes the early detection of infected partners, generally in the under-50 age group. The present findings corroborate Ministry of Health recommendations, as the over-50 age group showed a higher proportion of delayed initiation of therapy when compared to the population group aged 15-49 years.

As for geographic regional analysis, obeying the same logic of inequality of resources and distribution of health services found in other Brazilian studies, ${ }^{27}$ the South and Southeast presented the smallest proportions of patients with late initiation of ARVT. 
The differences by sex and region are associated with coverage of HIV-testing in those population groups. Data from the 2004 Brazilian Knowledge, Attitudes and Practices Survey showed 24\% lifetime HIV testing in men and $35 \%$ among women. Coverage of HIV testing also differs between Brazilian regions, ranging from $15 \%$ in the Northeast to $35 \%$ in the Southeast. ${ }^{9}$

Current testing technology makes it possible to discover HIV serostatus within minutes, with high sensitivity and specificity. ${ }^{28,29}$ In order to reduce the spread of disease and increase patient survival, it is necessary to promote HIV testing, especially among those individuals that do not feel they are at risk. Patients that begin ARVT late reduce the possibility of therapeutic success, consume more resources, and present lower survival rates.

The $\mathrm{CD}^{+}{ }^{+} \mathrm{T}$ lymphocyte count surveillance system allows for the monitoring of the proportion of HIV infected individuals with late initiation of ARVT. The results of this study show that the proportion of patients that start therapy in an advanced stage of the disease is still high, indicating the need to develop more effective strategies to promote early diagnosis of HIV infection nationwide in order to increase the impact of universal access to ARVT.

\section{RESUMO}

Souza-Jr, PRB, Szwarcwald CL, Castilho EA. Atraso na introdução de terapia antiretroviral em pacientes infectados pelo HIV no Brasil, 2003-2006. Clinics. 2007;62(5):579-84.

OBJETIVO: Caracterizar a população de indivíduos infectados pelo HIV que inicia tardiamente a terapia com anti-retrovirais (TARV) no Brasil, utilizando informações do Sistema de Controle de Exames Laboratoriais.

MÉTODOS: Foram analisados todos os indivíduos de 15 anos ou mais de idade que realizaram exame inicial para contagem de linfócitos $\mathrm{T} \mathrm{CD}^{+}$para avaliação de indicação de tratamento entre os anos de 2003 e 2006, cuja data de início da terapia foi posterior ou igual à data de solicitação da contagem de células T CD4+ (84694 pacientes). Esses pacientes foram considerados como virgens de tratamento com anti-retrovirais. A distribuição da contagem inicial de linfócitos $\mathrm{T} \mathrm{CD}^{+}$foi analisada por sexo, idade, Grande Região e ano de realização do exame.
RESULTADOS: A maioria dos pacientes tinha entre 15 e 49 anos de idade (91\%); $56 \%$ eram do sexo masculino; $76 \%$ assintomáticos; 50\% residiam na Região Sudeste e 20\% na Região Sul. A proporção de indivíduos cujo resultado do primeiro exame para contagem de linfócitos $\mathrm{TCD}^{+}$era inferior a $200 \mathrm{cel} / \mathrm{mm}^{3}$ foi de $33 \%$. Somando-se a esses os indivíduos sintomáticos, o valor atinge $41 \%$ para a totalidade; $47 \%$ para os homens e $53 \%$ para os pacientes com mais de 50 anos de idade.

CONCLUSÕES: Em que pese o acesso universal à TARV, no Brasil, os resultados mostram que uma alta proporção de pacientes inicia o tratamento em um estádio avançado da doença, apontando para a necessidade do estabelecimento de estratégias de diagnóstico precoce da infecção pelo HIV.

UNITERMOS: Linfócitos T CD4+ HIV. Aids. Terapia anti-retroviral. Brasil

\section{REFERENCES}

1. Bartlett JG, Gallant JE. Tratamento Clínico da infecção pelo HIV. Edição traduzida 2001-2002. Baltimore, Maryland: Johns Hopkins University; 2002 .

2. Chequer P, Cuchi P, Mazin R, Garcia Calleja JM. Access to antiretroviral treatment in Latin American countries and the Caribbean. AIDS. 2002;16(Suppl 3):S50-7.

3. Bastos FI, Kerrigan D, Malta M, Carneiro-da-Cunha C, Strathdee SA Treatment for HIV/AIDS in Brazil: Strengths, challenges, and opportunities for operations research. AIDScience. 2001;1(15).

4. Teixeira PR, Vitória MA, Barcarolo J. Antiretroviral treatment in resource-poor settings: the Brazilian experience. AIDS. 2004;18(suppl 3):S5-S7.
5. Levi GC, Vitória MA. Fighting against AIDS: the Brazilian experience. AIDS. 2002;16:2373-2383

6. Matida LH, Marcopito LF. Aumento do tempo de sobrevida das crianças com aids - AIDS - Boletim Epidemiológico, Ano XV nº2. 2002.

7. Marins JR, Jamal LF, Chen SY, Barros MB, Hudes ES, Barbosa AA, et al. Dramatic improvement in survival among adult Brazilian AIDS patients. AIDS. 2003; 17:1675-82

8. Brasil. Ministério da Saúde. Secretaria de Políticas de Saúde. Diretrizes dos Centros de Testagem e Aconselhamento - CTA: manual. Coordenação Nacional de DST e AIDS. Brasília: Ministério da Saúde, 1999. $32 \mathrm{p}$. 
9. Brasil. Ministério da Saúde. Secretaria de Vigilância de Saúde. Programa Nacional de DST e AIDS. Pesquisa de conhecimento Atitudes e Práticas na População Brasileira de 15 a 54 anos, 2004. Brasília: Ministério da Saúde; 2006. 175p.

10. Camargo-Jr KR, Coeli CM. Reclink: an application for database linkage implementing the probabilistic record linkage method. Cadernos de Saúde Pública. 2000;16:439-447.

11. Brasil. Ministério da Saúde. Secretaria de Vigilância Sanitária. Recomendações para Terapia Anti-Retroviral em Adultos e Adolescentes Infectados pelo HIV - 2006 (versão preliminar). Brasília: Ministério da Saúde, 2006. 85 p.

12. Severe P, Leger P, Charles M, Noel F, Bonhomme G, Bois G, et al. Antiretroviral therapy in a thousand patients with AIDS in Haiti. N Engl J Med. 2005;353:2325-34.

13. Egger M, May M, Chene G, Phillips AN, Ledergerber B, Dabis F, et al. Prognosis of HIV-1-infected patients starting highly active antiretroviral therapy: a collaborative analysis of prospective studies. Lancet. 2002;360:119-29.

14. Egger M and the Antiretroviral Therapy (ART) Cohort Collaboration. Prognostic importance of initial response n HIV-1 infected patients starting antiretroviral therapy: analysis of prospective studies. Lancet. 2003:362:679-686.

15. Szwarcwald CL, Carvalho MF, Barbosa-Júnior A, Barreira D, Speranza FAB, Castilho EA. Temporal trends of HIV-related risk behavior among Brazilian Military Conscripts, 1997-2002. Clinics. 2005;60:367-374.

16. Dybul M, Bolan R, Condoluci D, Cox-Iyamu R, Redfield R, Hallahan $\mathrm{CW}$, et al. Evaluation of initial $\mathrm{CD} 4^{+} \mathrm{T}$ cell counts in individuals with newly diagnosed human immunodeficiency virus infection, by sex and race, in urban settings. J Infect Dis. 2002;185:1818-21.

17. Klein D, Hurley LB, Merrill D, Quesenberry CP Jr; Consortium for HIV/AIDS Interregional Research. Review of medical encounters in the 5 years before a diagnosis of HIV-1 infection: implications for early detection. J Acquir Immune Defic Syndr. 2003;32:143-52.

18. Gay CL, Napravnik S, Eron JJ Jr. Advanced immunosuppression at entry to HIV care in the southeastern United States and associated risk factors. AIDS. 2006;20:775-8.

19. Girardi E, Aloisi MS, Arici C, Pezzotti P, Serraino D, Balzano R, et al. Delayed presentation and late testing for HIV: demographic and behavioral risk factors in a multicenter study in Italy. J Acquir Immune Defic Syndr. 2004;36:951-9.
20. Nacher M, El Guedj M, Vaz T, Nasser V, Randrianjohany A, Alvarez F, et al. Risk factors for late HIV diagnosis in French Guiana. AIDS. 2005; 19:727-9

21. Viacava F, Souza-Junior PR, Szwarcwald CL. Coverage of the Brazilian population 18 years and older by private health plans: an analysis of data from the World Health Survey. Cad Saude Publica. 2005;21(Suppl):119-28.

22. Lucena FF, Fonseca MG, Sousa AI, Coeli CM. O relacionamento de bancos de dados na implementação da vigilância da aids: Relacionamento de dados e vigilância da aids. Cadernos de Saúde Coletiva. 2006; 14:305-312.

23. Gupta SB, Gilbert RL, Brady AR, Livingstone SJ, Evans BG. CD4 cell counts in adults with newly diagnosed HIV infection: results of surveillance in England and Wales, 1990-1998. CD4 Surveillance Scheme Advisory Group. AIDS. 2000;14:853-61.

24. Brown AE, Tomkins SE, Logan LE, Lamontagne DS, Munro HL, Hope VD, et al. Monitoring the effectiveness of HIV and STI prevention initiatives in England, Wales, and Northern Ireland: where are we now? Sex Transm Infect. 2006;82:4-10.

25. Castilla J, Sobrino P, De La Fuente L, Noguer I, Guerra L, Parras F. Late diagnosis of HIV infection in the era of highly active antiretroviral therapy: consequences for AIDS incidence. AIDS. 2002;16:1945-51.

26. Easterbrook PJ, Yu LM, Goetghebeur E, Boag F, McLean K, Gazzard B. Ten-year trends in CD4 cell counts at HIV and AIDS diagnosis in a London HIV clinic. AIDS. 2000;14:561-71.

27. Souza Júnior, PRB; Szwarcwald, CL, Castilho, EA. HIV infection during pregnancy: the Sentinel Surveillance Project, Brazil, 2002. Revista de Saúde Pública. 2004:38:764-772.

28. Duarte G, Gonçalves CV, Marcolin AC, Paschaini MC, Quintana SM, Mussi-Pinhata MM. Teste Rápido para detecção pelo HIV-1 em gestantes. Revista Brasileira de Ginecologia e Obstetrícia. 2001;23:107-111

29. Carvalho RL, Krahe C, Farina G, Paula DO, Richetti N, Crossetti T. Teste Rápido para diagnóstico da infecção pelo HIV em parturientes. Revista Brasileira de Ginecologia e Obstetrícia. 2004;26:325-328. 